\title{
Performance Evaluation of The SIERA System at the Regional Assets Management Agency of the DKI Jakarta Provincial Government Using the COBIT 5 Framework
}

\author{
Nabilah Ayu Nindita ${ }^{a}$, Johan Setiawan ${ }^{\text {b }}$, Ahmad Faza \\ a, c Universitas Multimedia Nusantara, Jakarta, Indonesia
}

\begin{abstract}
Objective -To measuring and knowing the level of capability, the value of gaps, and recommendations for improvement for SIERA information system performance using the framework COBIT 5 based on the process APO08 Manage Relationship and BAI07 Manage Change Acceptance and Transitioning.

Methodology - This research uses a qualitative method and a quantitative method called the mixing method. The qualitative method is used to analyze the level of capability expected from the application of the SIERA information system based on the results of interview answers. In contrast, the quantitative method is used to analyze the level of capability that has been achieved so far based on the results of a questionnaire that has been filled out by four respondents determined by a convenient sampling technique.

Findings - The research found the results that the APO08 domain stopped at level 2, and the domain BAI07 stopped at desired level 1, so corrective actions need to be taken to reach the level expected level 4.

Novelty - By measuring the performance evaluation of the SIERA system, the Regional Asset Management Agency of DKI Jakarta Province can determine the level of capability that has been achieved and the value of the gap with the expected level of capability and assisting the Regional Asset Management Agency of the DKI Jakarta Provincial Government to take corrective actions based on recommendations from the findings in SIERA.

Keywords: APO08 Manage Relationship, BAI07 Manage Change Acceptance, and Transitioning, COBIT 5, DKI Jakarta Regional Asset Management Agency

JEL Classification: D24, E61, R11

Article info: Received July 2021; Revised August 2021; Accepted August 2021

Article Correspondence:

Recommended Citation: Nindita et al., (2021). Performance Evaluation of The SIERA System at the Regional Assets Management Agency of the DKI Jakarta Provincial Government Using the COBIT 5 Framework. Journal of Multidisciplinary Issues, 1 (2), 13-26.
\end{abstract}

\section{INTRODUCTION}

Implementation of IT Governance is a concept that is applied in government or public services and is intended for all agencies in the Republic of Indonesia as a way to increase productivity, effectiveness, and efficiency in performance and business processes in government or public services that have high complexity, so that all use of Information Technology in government is carried out optimally to achieve Good Governance (MT, 2012). Therefore, the application of the principles of Good Governance in the implementation of regional autonomy is a prerequisite for the effective implementation of regional autonomy (Akadun, 2007).

One of the government agencies that has implemented IT as a supporting tool for implementing and supporting government affairs in finance and asset management is the Asset Management Agency DKI Jakarta provincial government area (Badan Pengelolaan Aset Daerah Provinsi DKI Jakarta, n.d.). This is evidenced by the design, development, and implementation of SIERA, namely the Electronic Inventory System and Asset Reconciliation. SIERA was formed to facilitate, in particular, SKPD/UKPD Goods Managers in carrying out asset reconciliation activities, where all transactions made between SKPD/UKPD have gone through the system and are not done manually, as well as trying to assist the 


\section{JOURNAL OF MULTIDISCIPLINARY ISSUES}

Journal Website: www.jmis.site

J. Multi. Discp. Issues 1(2) 13-26 (2021)

financial reporting of the DKI Jakarta Provincial Government accurately (Widiyati, 2020).

SIERA has been officially launched and has been effectively used since 2018, but in its implementation until 2021, according to the results of a pre-interview conducted with Mr. Suripto Sastrowiyono as Head of the Sub-Sector for Data and Asset Information of the DKI Jakarta Provincial

Government BPAD, SIERA has several problems such as (1) lack of human resource capacity and capability, in this case, SKPD/UKPD as SIERA users in using SIERA, (2) the development of SIERA in the process is experiencing problems with established regulations, (3) business processes in SIERA is still not optimally implemented because several processes that adjust to high urgency for financial statements so that some processes that are running are not by following the applicable standard operating procedures.

Given this performance evaluation, research is conducted SIERA information system to determine that IT and IT governance, in particular, BPAD of Data and Information Sub fairly and efficiently by assessing the level capability of SIERA implementation using COBIT 5 framework. Important performed activity evaluation of Information System performance and Information Technology investment by measuring IT governance to know the level of IT governance capability in supporting business goals and ensuring service delivery for Evaluation in the event of an error as an effort to optimize the organization's business objectives (Wijaya \& Andani, 2017).

This research method uses the COBIT 5 framework that can be used as a recommendation for corporate IT Governance. COBIT 5 or Control Objective for Information and Related Technology is an international standard framework that can produce $\mathrm{n}$ assessment on IT governance as well as assessing the level of capability possessed by the IT organization. COBIT 5 has a reference process model consisting of 5 EDM, APO, BAI, DSS, and MEA domains and consists of a collection of 37 IT governance and management processes. Based on the assessment model used by ISO/IEC 15504, COBIT 5 has research standards that are more accurate, consistent, and objective (Mutiah, 2019) (Ring et al., 2018).

Based on the discussion of the problems described, the reference framework used is COBIT 5 with the process domain APO08 Manage Relationships, and BAI07 Manage Change Acceptance and Transitioning. All these calculation references are expected to help BPAD to utilize IT resources optimally to find out the results of the SIERA information system performance evaluation to get maximum results for business goals and IT goals that have been determined from the application of IT investments, in this case, SIERA development.

Some of the references used as literature reviews in this study were taken from Kuntadihardja, which conducted COBIT 5-Based Information System Audit Analysis in the APO11 Manage Quality subdomain (Kuntadihardja \& Tanaamah, 2019), and from Wella, which carried out Evaluation of the Alignment of Information Technology Strategy and Business Strategy in PT X uses the COBIT 5.0 Framework using the EDM01, EDM02, APO01, APO02, APO03, APO05, APO07, APO08, BAI01, and BAI02 processes (Wella \& Tanujaya, 2018), so that it becomes a reference for providing recommendations for implementation in SIERA system performance evaluation research at the Provincial Government BPAD DKI Jakarta Sub-Sector of Asset Data and Information, especially in managing relationships and managing acceptance of changes and transitions.

Based on the background of the problem that has been described, the problems to be discussed are: (1) What are the results of the Evaluation of the SIERA Information System at the DKI Jakarta Provincial Government BPAD for Data and Information using the COBIT 5.0 framework with the APO08 Manage Relationship and BAI07 Manage Change Acceptance and Transitioning processes?; (2) What are the appropriate recommendations for improvement according to the COBIT 5.0 framework for the APO08 Manage Relationship and BAI07 Manage Change Acceptance and Transitioning processes on the results of the SIERA Information System evaluation at BPAD DKI Jakarta, Data and Information Sub-Sector.

This study aims to measure and determine the level of the performance capability of the SIERA information system using the COBIT 5 framework based on the APO08 domain and the BAI07 domain, determine the value of the gap in the APO08 and BAI07 processes, and assist the Data and Information Assets Sub-Sector as the party that builds and develops SIERA in making recommendations for corrective activities to manage IT governance of the SIERA system in achieving the expected goals. 


\section{JOURNAL OF MULTIDISCIPLINARY ISSUES}

Journal Website: www.jmis.site

J. Multi. Discp. Issues 1(2) 13-26 (2021)

\section{LITERATURE REVIEW}

\section{Evaluation of Information Systems}

Evaluations of Information Systems are a very important part of the organization for the measurement of the effectiveness of the strategies used to achieve organizational goals (Agani et al., 2018).

The purpose of Evaluation is to objectively collect and evaluate evidence of problems related to behavior or events, compare them with predetermined standards, and inform interested parties about the results as relevant material for further Evaluation and development (Laksmidewi et al., 2017).

\section{Objectives of Information System Evaluation}

The objectives and functions of Information System Evaluation as mentioned in the journal article are as follows (Agani et al., 2018):

1. To find out the achievement of the goals that have been set

2. To provide objective observations of the results of information systems

3. To provide objective observations of the results of information systems

4. To determine the capabilities and determine the feasibility of the information system.

5. To provide feedback for activities that have been or are being carried out in the system.

Information system evaluation can be done by reviewing information technology governance to optimize government to achieve good governance (MT, 2012).

\section{IT Governance}

Information technology governance is a structure that focuses on information technology and risk management within the company. Information technology governance directs and controls the company's information technology (IT) in line with the company's business objectives. Information technology governance also provides direction for organizations to manage and manage IT resources by considering the supervision and control of IT resources that have been established by the company (Wiraniagara \& Wijaya, 2019).

There are several frameworks or frameworks as guidelines for IT governance, namely the Information Technology Infrastructure Library (ITIL), The Open Group Architecture Framework (TOGAF), and Control Objectives for Information and related Technology (COBIT). ITIL focuses on customer service, TOGAF is used to develop the company architecture process with the ADM phase, while COBIT is used for COBIT 5 Information Technology (IT) management.

This study uses the COBIT 5 framework because it is in accordance with the urgency of the problems that occurred in BPAD in SIERA. Besides that, there is one of the principles in COBIT 5, namely determining the needs of stakeholders (Syuhada, 2021), where this principle is deemed appropriate to overcome the basic problems contained in the application of the SIERA system designed and developed by BPAD in the Data and Information sub-sector before carrying out further development, and COBIT 5 also has advantages compared to other frameworks because the processes in COBIT 5 are more holistic, complete, and include business and IT activities end-to-end (Miranti, 2019).

\section{COBIT 5}

COBIT 5 is a framework developed and published by ISACA (Association of Information Systems Audit and Control) in 2012. COBIT 5 guides organizations in achieving organizational goals related to IT Governance and IT management. COBIT 5 provides a framework that has a broad scope to support the creation of alignment between IT implementation and business objectives. COBIT 5 enables information and related technologies to be organized and managed as a whole and pertinent for the entire organization, covering the entire business process and functional areas of responsibility and taking into account the ITrelated interests of internal or external stakeholders (ISACA, 2012).

COBIT 5 is based on five key principles for governance and enterprise IT management. The fifth principle of COBIT 5 will namely Meet stakeholder needs, Covering enterprise end-to-end, Applying a single integrated framework, Enabling a holistic approach, and Separating governance from management 


\section{JOURNAL OF MULTIDISCIPLINARY ISSUES}

Journal Website: www.jmis.site

J. Multi. Discp. Issues 1(2) 13-26 (2021)

(ISACA, 2012).

a. Meeting stakeholder needs

The company creates a business value for stakeholders or stakeholders with the balance between benefits realized and optimization of risk and use of resources. COBIT 5 provides all the processes needed to support business value creation through IT deployments. Because each company has different goals, companies can adapt COBIT 5 to the existing business flow with Enterprise Goals, translate the company's highest goals with IT Related Goals, and perform mapping or mapping in specific processes.

b. Covering enterprise end-to-end

COBIT 5 integrates corporate IT governance with two types of integration, namely:

- COBIT 5 covers all functions and processes within the company, so COBIT 5 does not focus solely on IT functions but makes information and technology an asset that needs to be handled just like any other asset by everyone in the company.

- COBIT 5 considers all available resources in the company as mutually supporting and influencing parts, so COBIT 5 considers all IT-related governance supporters and management from an end-to-end perspective.

c. Applying a single integrated framework

COBIT 5 is governance that discusses and provides high-level guidance in detail regarding governance and management of corporate IT, and 5 has standards and best practices to provide guidance related to IT activities and sub-activities.

d. Enabling a holistic approach

COBIT 5 defines a set of enablers to support the implementation of a comprehensive governance and management system for Enterprise IT. Enabler is defined as anything that can help achieve company goals. The seven enabler categories in COBIT 5 include (1) Principles, Policies, and Frameworks; (2) Processes; (3) Organizational Structure; (4) Culture, Ethics and Behavior; (5) Information; (6) Services, Infrastructure and Applications; (7) People, Skills and Competencies;

e. Separating governance from management

COBIT 5 provides a separate explanation between management and governance. Both of these represent different activities, require different organizational structures, and perform services to achieve different goals. The following is an explanation for Governance and Management:

- Governance ensures the needs, conditions, and choices of stakeholders will be evaluated to determine the agreed objectives to be achieved by the company. The purpose of governance is to provide direction for setting priorities and making decisions. In addition, governance also monitors performance and conformity to agreed objectives.

- Management includes planning, development, and monitoring activities that are aligned with the directions set by the governance organization to achieve the objectives of the company.

\section{Process Assessment Model}

The Process Assessment Model is the basic model for assessing a company's IT process capability against COBIT 5 and training and certification programs for assessors. An evidence-based assessment process to produce a reliable, consistent, and repeatable assessment process in the IT governance and management area (ISACA, 2013).

In the Process Assessment Model, there are six levels of capability, namely:

1. Level 0, Incomplete Process

2. Level 1, Performed Process

PA 1.1 Process Performance Attribute

3. Level 2: Managed Process

PA 2.1 Performance Management Attribute

PA 2.2 Work product Management Attribute 
4. Level 3: Established Process

PA 3.1 Process Definition Attribute

PA 3.2 Process Deployment Attribute

5. Level 4: Predictable Process

PA 4.1 Process Measurement Attribute

PA 4.2 Process Control Attribute

6. Level 5: Optimizing Process

PA 5.1 Process Innovation Attribute

PA 5.2 Process Optimization The Attribute

Process Attribute (PA) is assessed based on the range of values below:

1. N (Not achieved): $0-15 \%$.

2. P (Partially achieved): $15-50 \%$.

3. L (Largely achieved): $50-85 \%$

4. F (Fully achieved): $85-100 \%$

\section{Capability Level}

Capability Level will achieve the same process objectives by measuring the overall assessment and supported by process improvement, namely by providing a means to measure the performance of each governance process or management process and being able to identify areas of performance improvement that need to be improved.

There are six levels of capability levels in the COBIT 5 process (ISACA, 2012):

1. Level 0 - Incomplete process

The process was not implemented or failed to achieve its process objectives. At this level, there is little or no evidence of systematic achievement of the process objectives.

2. Level 1 - The performed process

The implemented process achieves its process objectives.

3. Level 2 - The managed process

The previous processes are now implemented in the management phase (planned, monitored, and adjusted), and the work results are defined, controlled, and maintained.

4. Level 3 - The established process

The previously managed processes are now implemented using defined processes to achieve their process outcomes.

5. Level 4 - Predictable process

The previously defined processes are now operating within the defined limits to achieve their process outcomes.

6. Level 5 - Optimising process

The previously predictable processes are now continuously improved so that business objectives are met in a relevant and projectable manner.

\section{Gap Value}

The Gap Value or Gap Level in COBIT 5 is the distance between the capability value obtained or currently occurring with the expected capability value (Asnal \& Jamaris, 2018).

\section{RACI Chart}

The RACI diagram is part of the Responsibility Assignment Matrix (RAM) which is a form of mapping between resources and activities in each process (Rasyid, 2015).

A value is given in the form of R/A/C/I, which stands for $\mathrm{R}$ (Responsible), indicating that the section is the executor and must be responsible for carrying out and completing the activities under his responsibility, A (Accountable) indicates that the party must direct the implementation of the activity, $\mathrm{C}$ (Consulted) indicates that the section is the party that will be the place of consultation during the activity, 
and I (Informed) indicates that the section is the party who was given information during the activity going on.

\section{Information System Audit Stages}

Based on the theories that have been studied, it can be concluded that an information system audit can add business value to an organization if it is done. To achieve this goal, several stages need to be carried out, including the audit stage; according to Gallegos in his book entitled "Information Technology Control and Audit," there are four stages as follows (Senft, Sandra. Gallegos, 2008):

1. Planning

At this stage, identification of the scope for which IT governance evaluation will be carried out, things to be achieved from the information system audit activities, this is determined from the scope of research, research objects, vision and mission objectives of the research object, and strategies and policies related to the processing of investigations.

2. Field Work

At this stage, data collection that has been obtained from the observation, interviews, and questionnaires is carried out to obtain evidence of assessment.

3. Reporting

At this stage, do a recap of the entire process to obtain and determine the value of the Capability Level at APO08 and BAI07 on information systems Sierra, then performed checks on the requirements that must be met at each level with pre-defined categories based on assessment results at each level, then the evaluation results are presented in the form of findings, activities in each process, and gap values to provide.

4. Follow Up

At the last stage of the capability level assessment, an assessment document is produced, the achievements that have been obtained, as well as recommendations for corrective actions for the Asset Data and Information Sub-Sector to improve processes that have not been maximized. The corrective action recommendations given are based on the framework COBIT 5. The results of this research will be given to the Head of the Data and Information Assets Sub Division to decide whether the recommendations given are accepted or not.

\section{RESEARCH METHODOLOGY}

The sampling technique in this study uses the technique Convenient Sampling by taking several people from the whole and selecting samples from people who are easily accessible, then the interview activities and respondents filling out the questionnaire will be given to the Head of the BPAD Asset Data and Information Sub Division as interview respondents and respondents questionnaire, then 3 BPAD staff as respondents to other questionnaires relevant to the SIERA system including 1 PIC in charge of SIERA, 1 SIERA system analyst, and one programmer who developed SIERA, because these four individuals can represent users of the SIERA information system.

Data collection techniques in this study were conducted by interview, questionnaire, and observation. Interviews conducted in the data collection stage were conducted by asking questions in accordance with the focus of domain of the selected COBIT 5 process used in this study. Interviews were conducted in a predetermined sequence and words or called Standard Open-Ended Interviews, then additional questions were added from the spontaneous development of answers to previous questions. There is no limit to answers from respondents, and avoiding yes or no answers when conducting interviews with respondents, but rather by explaining what is being asked. Interview questions were delivered sequentially according to the selected COBIT 5 process activities, and there were some developments from the questions asked due to the answers from respondents.

Observations were made on the Sub-Sector of Data and Asset Information of BPAD to find, collect, and identify information related to SIERA for research purposes. Observations are made by collecting 
information related to the documents in the SIERA system and seeing how the SIERA system works.

The questionnaire created and used in this study was adapted to the selected COBIT 5 process, which was the focus of this study. Respondents can answer every question in the questionnaire by providing an assessment according to the reference Capability Level in COBIT 5.

The research method used is the Mix Method because the data analysis technique uses two types of data, namely qualitative and quantitative. The analytical technique used is to analyze the level of capability expected from the application of the SIERA information system based on qualitative data from the results of interview answers with predetermined questions and words as well as the addition of other questions originating from the development of answers to previous questions that are spontaneous, and also analyze the level of capability that has been achieved so far based on quantitative data from the results of questionnaires that have been filled out by respondents.

From the results of the analysis of qualitative data and quantitative data, and analysis of the calculation of the level of capability level of the SIERA system governance at the DKI Jakarta Provincial Government BPAD was carried out. This research will examine the gap that occurs in the level of capability. At the stage of analyzing the gaps in the process, what is done is to compare the results of the assessment of the current level of governance capability with the expected level of governance capability, then analyze the problems and findings in the SIERA information system governance. In addition, from the problems and findings, the researcher provides suggestions and recommendations for corrective activities that can be used to improve and develop the performance of the SIERA system to be able to fill the gap between existing achievements and the goals to be achieved.

How to calculate the level of capability in the COBIT 5 framework is to assign a value to all activities that have been determined in the mapping processor mapping into the COBIT 5 process, where the activities in the process are used to create a questionnaire. The provisions in COBIT 5 to provide an assessment of these activities are carried out based on the value of the process assessment model in COBIT 5.

\section{SIERA}

Asset Reconciliation Electronic Information System (SIERA) is a system built by the Regional Asset Management Agency of the DKI Jakarta Provincial Government to make it easier, especially for SKPD/UKPD Goods Managers in carrying out asset reconciliation activities, where all transactions made between SKPD/UKPD have gone through the system and not done manually. It is hoped that this system can minimize the error in calculating the value of an asset (Modul Siera, n.d.)

\section{COBIT 5}

In this study, the COBIT 5 framework was determined as the research method because COBIT 5 provides a reference process model that represents all general processes related to activities at BPAD DKI Jakarta Province Asset Administration Sector Asset Data and Information Sub-sector, COBIT 5 also provides a framework to measure and monitor IT performance, communicate with services, and integrate best management practices and provide complete direction from quality systems, planning, project management, security, development and service management (ISACA, 2012).

\section{FINDINGS AND RESULT}

\section{Planning}

SIERA is managed by the Sub Division of Information and Asset Data at BPAD DKI Jakarta Province. 
JOURNAL OF MULTIDISCIPLINARY ISSUES

Journal Website: www.jmis.site

J. Multi. Discp. Issues 1(2) 13-26 (2021)

The function of the SIERA information system is in line with the vision and mission to be achieved by BPAD in carrying out its functions and duties as a regional asset manager, namely to realize and implement accountable, transparent, responsive, and participatory regional asset management, which is realized by managing asset information systems as a form of achieving regional asset accountability and

can provide fast and accurate services to stakeholders and have a professional regional asset management apparatus.

In practice, SIERA is still experiencing several problems, and there has never been an IT governance evaluation on the SIERA system using a framework so that in this study, an assessment of the SIERA information system performance will be carried out by calculating the capability level of the system using the COBIT 5 framework guidelines first. First, carry out the process mapping or mapping in accordance with the COBIT 5 framework guidelines.

The sequence of the planning stages begins with the determination of Enterprise Goals, then IT-Related Goals, until the determination of the COBIT 5 process. The selection of Enterprise Goals is carried out to determine the main objectives of the Data and Information Sub-Sector in building and developing SIERA; Enterprise Goals are determined based on the vision and mission of the research object. Where the object in this research is the SIERA system which then can be useful for the next stage in this research. There are 17 lists of Enterprise Goals have been provided in COBIT 5; later, from the 17 lists, a ranking is given by the parties concerned in the object of research.

IT-Related Goals are obtained based on Enterprise Goals predetermined. IT-Related Goals are obtained from the primary status in the Enterprise Goals that have been given a ranking, and then the status reviewed primary contained in the Enterprise Goals is to select IT-Related Goals.

The next stage after determining the IT-Related Goals is the determination of the COBIT 5 process obtained from the status primary on the IT-Related Goals selected.

The next stage is the selection of the domain of the COBIT 5 process, which has become a priority so that it can be continued in the calculation analysis Capability Level.

\section{Field Work}

The field inspection stage contains an explanation of the results of interviews, observations, and questionnaires conducted in this study.

In the interview process, the head of the Asset Information Data Sub Division said that the expected output in the SIERA system should be an asset report, but for the purposes of financial reports, the current output is a financial report, so that in addition to managing assets, SIERA also manages finances related to assets. He also mentioned that the problem that has occurred to SIERA is that SIERA's business processes are not yet optimal due to overlapping standard operating procedures or regulations and the lack of competent human resources. The next problem is the process of calculating asset depreciation in the SIERA system, which is still not optimal because the formula changes every time to adjust the findings in the field so that it affects the application of the source code used in the system.

In the observations process, a total of 33 APO08 documents were checked for availability based on the ISACA COBIT5 (Process Assessment Model), and only five documents were available, and 28 other documents were not available. The five documents available are Review Results of Quality of Service, Including Customer Feedback, Maintenance Plan, Clarified and Agreed-On Business Expectations, Agreed-On Next Steps and Action Plans, and Agreed-On Key Decisions, where the five documents are named different from the documents available at the Data and Information Sub-Division BPAD but the contents have been adjusted to conform to the documents available on APO08.

In the BAI07 process, a total of 26 documents were checked for availability based on the ISACA COBIT5 (Process Assessment Model), and only five documents were available, and 21 other documents were not available. The five available documents are Approved Requests for Change, Test Result 
Communications, Approved Internal Implementation Plan, Approved Acceptance Test Plan, and Test Data, where the contents of the five documents have been adjusted to the existing documents in BPAD.

In the questionnaires process, based on the calculation of the APO08 Process Questionnaire Level 1, the value achieved in the domain APO08 level 1is $85.567 \%$. This means that the APO08 process can be continued to the next stage, namely level 2 . It was found that the parties related to the SIERA system did not fully understand business expectations from the relationship between business and IT that is applied, standard operating procedures or regulations that are still not clearly defined, business processes in the SIERA system are dynamic so that not all related parties can understand the developments and changes that occurs and there is still a lack of collaboration activities in agreeing on steps initiative step.

Based on the calculation of the APO08 Level 2 Process Questionnaire, that the average value achieved in the APO08 level 2 process is $84.375 \%$, indicating that the process cannot be continued to the next stage, namely level 3. It was found that the objectives for the SIERA system process performance have been identified, process performance the SIERA system has been planned and monitored, the performance of the SIERA system process has been adjusted to meet the BPAD plan for the data and information subsector, the responsibilities and authorities for carrying out the process have been defined, assigned and communicated, the resources and information needed to carry out the process in the SIERA system have been identified, available, allocated and used properly, meetings between the parties involved have been managed and communicated effectively, as well as clear assignments of responsibilities, some requirements for SIERA system outputs have not been fully defined, there is documentation of SIERA system output results, outputs from the SIERA system are identified, documented and not controlled properly because errors still occur, and there are no defined SOPs and requirements for reviewing the outputs of the SIERA system.

Next is the calculation of the Process Questionnaire BAI07 Level 1, the value achieved in the domain BAI07 level 1is $74.68 \%$; this can mean that the BAI07 process cannot be continued to the next stage, namely level 2. It was found that the planning for implementation is still not well documented, no practice tests are carried out conversion before direct conversion, did not conduct a test plan to discuss the potential for internal accreditation, had not fully identified the required resource requirements, had not consistently stored and documented test results, had not carried out system performance testing based on the test plan, lack of documentation in terms of record the items which have been distributed, the lack of additional resources due to the constrained procurement process, yet perform consistently review, postimplementation as well as inconsistent for consultation with business process owners in determining the success and achievement metrics SIERA.

\section{Reporting}

At the reporting stage, the results of the research are presented from the data collected during field inspections or fieldwork. After getting the data, then calculating and analyzing the target capability level to be achieved, analyzing the findings and impacts found in the APO08 and BAI07 domains, providing recommendations for improvement, and also recommendations for achieving targets. The following are the results obtained from the interviews:

1. In the Asset Data and Information Sub-Sector, four parties are members of the SIERA design, establishment, and development team, namely the Head of the Data and Information Sub-Sector, one programmer, one system analyst, and 1 Person In Charge of the position of a civil servant as the guarantor responsible for the SIERA system and as the person in charge of the bureaucracy in the SIERA system.

2. Sub Sector Data and Information Assets have never been audited SIERA information system using 
a framework.

3. The expected output in the SIERA system should be an asset report, but for the purposes of financial statements, the current output is a financial asset report, so that in addition to managing assets, the SIERA system also manages finances related to assets.

4. SIERA's business processes are still not optimal due to overlapping standard operating procedures or regulations

5. Lack of competent human resources

6. The process of calculating asset depreciation in the SIERA system is still not optimal because the formula changes from time to time to adjust the findings in the field so that it affects the application of the source code used by programmers in the system.

At the observation stage, the available documents are checked based on the ISACA manual, namely Process Assessment Model (PAM): Using COBIT 5, and by doing direct observations on the environment of the research object in the Data and Information Sub-Sector.

At this stage, the questionnaire is filled out by respondents who have been determined using the Convenient Sampling technique then determined and adjusted using the RACI chart APO08 and BAI 07. The respondents who were addressed in this study were four people, namely the Head of the Data and Information Sub-Sector, SIERA Programmer, Person In Charge system. SIERA, and SIERA Systems analyst.

Table 4. 1: Calculation table for all Domains at level 1

\begin{tabular}{|l|l|l|l|l|}
\hline Domain & \multicolumn{1}{|c|}{ Description } & Avg score & \multicolumn{1}{c|}{ Status } & Explanation \\
\hline APO08 & $\begin{array}{l}\text { Manage } \\
\text { Relationship }\end{array}$ & $85,567 \%$ & $\begin{array}{l}\text { Fully } \\
\text { Achieved }\end{array}$ & Up to level 2 \\
\hline BAI07 & $\begin{array}{l}\text { Manage Change } \\
\text { and Acceptance }\end{array}$ & $74,68 \%$ & $\begin{array}{l}\text { Largely } \\
\text { Achieved }\end{array}$ & Stop at level 1 \\
\hline
\end{tabular}

Table 4. 2: APO08 Level 2 Domain Questionnaire Calculation

\begin{tabular}{|c|c|}
\hline \multicolumn{2}{|c|}{ APO08 } \\
\hline Activity & Avg score \\
\hline PA 2.1 Performance Management & $100 \%$ \\
\hline PA 2.2 Work Product Management & $68,75 \%$ \\
\hline Average & $\mathbf{8 4 , 3 7 5 \%}$ \\
\hline
\end{tabular}

Table 4. 3: APO08 and BAI07 Achievement Table

\begin{tabular}{|l|c|c|c|c|c|c|}
\hline No & Process & Level 1 & Level 2 & Level 3 & Level 4 & Level 5 \\
\hline 1 & APO08 & F & L & N & N & N \\
\hline 2 & BAI07 & L & N & N & N & N \\
\hline
\end{tabular}




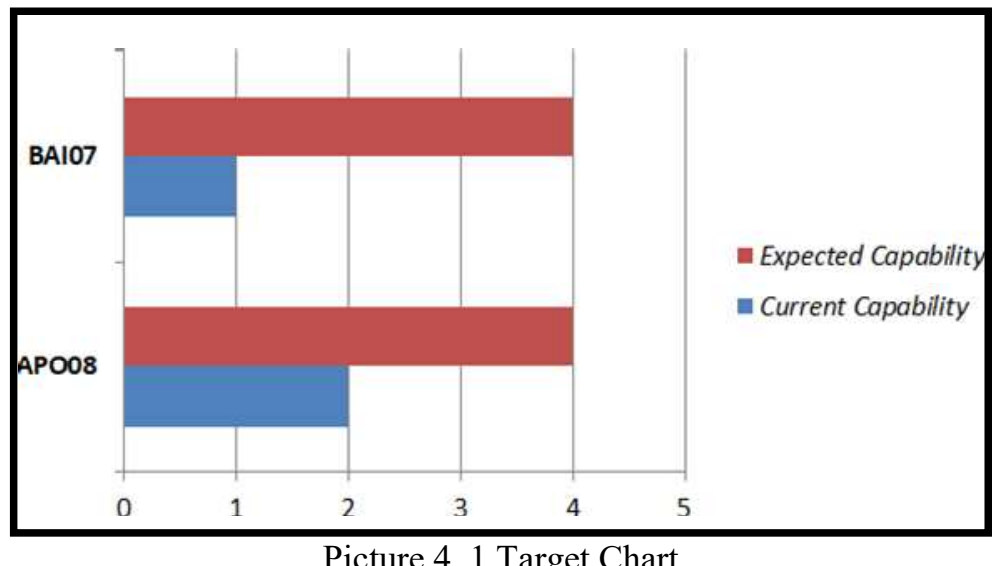

As can be seen from the target graph in Figure 4.1, that the Asset Data and Information Sub-Sector has not fulfilled all the processes on the target to be achieved, namely level 4 . The achievement value in the SIERA system IT governance evaluation is divided into two processes; namely, the APO08 process stops at level 2, and The BAI07 process stops at level 1, so there is a gap value in the APO08 process of 2 and the BAI07 process of 3 .

This is because there are still many criteria based on each process that has not been carried out completely or consistently, such as the lack of understanding of the parties. Related to business expectations from the relationship between IT and business at SIERA, collaboration activities are still not consistently carried out to agree on the initial steps to be implemented, the implementation of standard operating procedures that are still overlapping, dynamically changing business processes result in not all parties understanding process change and development $\mathrm{s}$, the lack of test planning, inconsistency in the process of recording tests, test results, and post-implementation reviews of SIERA which resulted in the two domains being tested, namely APO08 at level 2 and domain BAI07 at level 1.

This proves that some corrective actions need to be taken. To improve several things so that the expected target can be achieved, namely at level 4 . The following are the major findings of the SIERA system:

1. The SIERA system standard operating procedures have not been identified and implemented in accordance with the directions and objectives of the SIERA system.

2. Human resources are not competent in implementing the SIERA system process.

3. SIERA system stakeholders have not carried out their responsibilities optimally in carrying out business functions or processes in the SIERA system.

4. Lack of monitoring measures on the performance of the SIERA system stakeholders.

5. Have not carried out documentation of implementation planning, transition, testing, and review while implementing the implementation of the SIERA system in a consistent and well-structured manner.

6. Have not documented the results of implementation, transition, testing, and review during the implementation of the SIERA system in a consistent and well-structured manner.

After finding major findings that are inhibiting factors in the implementation and implementation of the 


\section{JOURNAL OF MULTIDISCIPLINARY ISSUES}

Journal Website: www.jmis.site

J. Multi. Discp. Issues 1(2) 13-26 (2021)

SIERA system, recommendations for corrective activities for improvement have been determined. The recommendations are based on the COBIT 5 framework guidelines, which are as follows:

1. It is necessary to establish SOPs that have been identified in accordance with the directions and objectives of the implementation of SIERA.

2. Carry out regular training for SIERA users with the aim of being able to carry out effective communication and monitoring actions to the extent of stakeholder understanding of SIERA business processes.

3. Need to define, communicate and assign responsibilities and authorities to each stakeholder SIERA.

4. They are adding human resources and forming a special division to carry out monitoring actions on the performance of SIERA stakeholders.

5. Carry out planning and documentation of implementation planning, transition, testing, and review before or after the implementation of the SIERA system in a consistent and structured manner.

6. Recording and documenting the results of planning implementation, transition, testing, and review during the implementation of the SIERA system in a consistent and structured manner.

\section{Follow Up}

Follow up or feedback on recommendations that have been made based on the findings in the SIERA system is submitted to the head of the DKI Jakarta Provincial Government BPAD Asset Data and Information Sub Division to find out whether the recommendations given are approved or not to be applied as a reference for corrective actions. In improving SIERA's IT governance to improve SIERA's information system performance.

\section{CONCLUSION AND RECOMMENDATIONS}

The results of this research can be concluded that the process of measuring the capability level of SIERA IT governance through the evaluation of SIERA's performance in the data and information subfield of BPAD, that is, there are results from mapping or mapping based on COBIT 5, namely the APO08 Manage Relationship and BAI07 Manage Change Acceptance and Transitioning. The results of after interviews, observations, and value calculations are based on questionnaires that have been filled out by 4 individuals who are members of the SIERA development and development team, namely the Head of the Asset Data and Information Sub Division, the Person In Charge in charge of SIERA (with the position of PNS), SIERA system analyst, as well as the SIERA programmer, it can be concluded that:

1. APO08 Manage Relationship is done completely and stops at level 2 at a percentage of $84.375 \%$, while the organization's target is to reach level 4.

2. BAI07 Manage Change Acceptance and Transitioning is only done mostly and stops at level 1 at a percentage of $74.68 \%$, while the organization's target is to reach level 4 .

To achieve the target level of capability to level 4, the DKI Jakarta BPAD Asset Data and Information SubSector need to make recommendations for improvement, including:

1. Ensuring that the implemented processes have achieved the 131 objectives of the process

2. Managing the performance of the SIERA system process

3. Managing, defining, and control the output generated by the SIERA system.

4. Maintain process standards to support the development of defined processes

5. Apply process standards effectively as defined processes to achieve process outcomes

6. Use and ensure that process performance can support the achievement of process performance objectives relevant to defined business objectives 
7. Ensure that processes are managed effectively by quantitative methods to produce a process that is stable, capable, and predictable within a specified time limit.

\section{REFERENCES}

Agani, M. Al, Munadi, R., \& Subianto, M. (2018). Evaluasi Kinerja Sistem Informasi Akademik Menggunakan IT Balanced Scorecard Pada Universitas Serambi Mekkah Banda Aceh. Jurnal Informatika Upgris, 4(1). http://journal.upgris.ac.id/index.php/JIU/article/view/2071

Akadun. (2007). Good Governance dalam Otonomi Daerah. Sosiohumaniora: Journal of Social Sciences and Humanities, 9(1), 37-47. http://jurnal.unpad.ac.id/sosiohumaniora/article/view/5375

Asnal, H., \& Jamaris, M. (2018). Evaluasi IT Governance pada Sistem Elektronik Evaluasi Dosen Oleh Mahasiswa (E-EDOM) Dengan Menggunakan Framework Cobit 5. JTT (Jurnal Teknologi Terpadu), 6(2). https://pdfs.semanticscholar.org/4582/3c84019c5ffb9a48e443a2418a861d45e8dd.pdf

ISACA. (2012). A Business Framework for the Governance and Management of Enterprise IT. In Trust And Partnership. https://doi.org/10.1002/9781119203919.ch11

ISACA. (2013). COBIT ${ }^{\circledR}$ Process Assessment Model (PAM): Using COBIT ${ }^{\circledR} 5$.

Kuntadihardja, C. H., \& Tanaamah, A. R. (2019). Analisis Audit Sistem Informasi Berbasis COBIT 5 Pada Subdomain APO11 Manage Quality. Jurnal SITECH: Sistem Informasi Dan Teknologi, 2(1), 109-120. https://doi.org/10.24176/sitech.v2i1.3492

Laksmidewi, A., Linawati, L., \& I.M.O, W. (2017). Evaluasi Sistem Informasi Manajemen Kepegawaian dengan DS5 dan DS9 COBIT 4.1 Studi Kasus : Pemprov Bali. Majalah Ilmiah Teknologi Elektro, 17(1), 25. https://doi.org/10.24843/mite.2018.v17i01.p04

Miranti, A. (2019). Evaluasi Tata Kelola Teknologi Informasi Menggunakan Framework COBIT 5 (Studi Kasus: PT Praweda Ciptakarsa Informatika). In Journal of Chemical Information and Modeling (Vol. 53, Issue 9).

Modul Siera. (n.d.). Retrieved October 13, 2020, from https://www.scribd.com/document/391978446/14Modul-Siera-pdf

MT, I. K. (2012). Kajian It Governance Untuk Peningkatan Produktivitas Operasional Pelayanan Publik. CCIT Journal, 6(1), 47-56. https://doi.org/10.33050/ccit.v6i1.377

Mutiah, N. (2019). Penilaian Tata Kelola Teknologi Informasi Universitas Tanjungpura Menggunakan Cobit 5 Domain Align, Plan, Dan Organise (APO). Computer Engineering, Science and System Journal, 4(1), 65. https://doi.org/10.24114/cess.v4i1.11457

Rasyid, A. Al. (2015). Analisis Audit Sistem Informasi Berbasis COBIT 5 Pada Domain (DSS) (Studi Kasus : SIM-BL di Unit CDC PT Telkom Pusat.Tbk). Telkom Engineering School, Telkom University.

Ring, J., Utara, R., Depok, K., Sleman, K., \& Yogyakarta, D. I. (2018). Evaluasi Penerapan Cobit 5 Pada Layanan Pengadaan Secara Elektronik ( Lpse ) Di Provinsi Gorontalo. METIK Jurnal, 2(1), 40-45.

Senft, Sandra. Gallegos, F. (2008). Information Technology Control and Audit. In Journal of Chemical Information and Modeling (3rd Editio, Vol. 53, Issue 9). https://doi.org/10.1201/9781420065541

Syuhada, A. M. (2021). KAJIAN PERBANDINGAN COBIT 5 DENGAN COBIT 2019 SEBAGAI FRAMEWORK AUDIT TATA KELOLA TEKNOLOGI INFORMASI. 6(1), 1-14. https://doi.org/30 http://dx.doi.org/10.36418/syntax-literate.v6i1.2082

Wella, W., \& Tanujaya, A. F. (2018). Evaluasi Penyelarasan Strategi Teknologi Informasi dan Strategi Bisnis di PT X Menggunakan Kerangka Kerja COBIT 5.0. Jurnal ULTIMA InfoSys, 8(2), 81-86. https://doi.org/10.31937/si.v8i2.617

Widiyati, vina tri. (2020). BPAD DKI Jakarta. https://bpad.jakarta.go.id/portal/content/berita/4284

Wijaya, A. F., \& Andani, A. T. (2017). Evaluasi Kinerja Sistem Informasi E-Filing Menggunakan Cobit 5 Pada Kantor Pelayanan Pajak Pratama Kota Salatiga. Jurnal Terapan Teknologi Informasi, 1(1), 61-70. 
https://doi.org/10.21460/jutei.2017.11.9

Wiraniagara, A., \& Wijaya, F. (2019). Analisis Tata Kelola Teknologi Informasi Menggunakan Framework Cobit 5 Domain Deliver Support and Service ( Studi Kasus : Yayasan Eka Tjipta, Jakarta ). Sebatik, 5, 663-671. 